\title{
The Impact of Digitalization on Business Sector Development in the Knowledge Economy
}

\author{
Daniela Mihaela NEAMŢU \\ "Ștefan cel Mare" University, Suceava, Romania \\ dana_neamtu99@yahoo.com \\ Cristian-Valentin HAPENCIUC \\ "Ştefan cel Mare" University, Suceava, Romania \\ valentinh@seap.usv.ro \\ Ruxandra BEJINARU \\ "Ştefan cel Mare" University, Suceava, Romania \\ ruxandrabejinaru@yahoo.com - corresponding author
}

\begin{abstract}
The economic progress of the last century has made the world seem smaller, has shortened distances and provided an increase in the efficiency with which the 'time' resource is used. Currently, due to technological advancement, change and diversification of the means of communication, we can get in touch or chat with another person in every corner of the world, no matter how far. Moreover, technology imports raise standards of living and bring improvements to the service sector. The digital revolution is not only present, but it is increasing every day. Knowledge fundamentally transforms every sector of our economy - from health up to transport and energy and beyond. The scope, magnitude and omnipresence of these disruptive innovations are truly unprecedented. The objective of our work is to present the theoretical approaches regarding the information society and its quantification in Romania and in the European context on the basis of specific indicators. By analyzing these indicators, we try to demonstrate the position of our country at world level in terms of ICT. In order to analyze comparatively the situation of ICT and their impact on the business sector, two major indicators for this field were analyzed - the State ICT Development Index (IDI) and the DESI Index.
\end{abstract}

Keywords: ICT, knowledge economy, digitalization, technology 4.0, technological innovations.

\section{Introduction}

In the knowledge era is developing also a knowledge society - which some authors call an informational society, and others - a digital society. But no matter what name they are given, many authors complied to a general, unique definition. The products specific to the contemporary information and communication technology recorded a significant dynamics (Drucker, 2001; Ghinea et al., 2017; Rifkin, 2004). Thus, if in 2010, 62.7\% of enterprises with 10 employees used broadband connections (Internet), nowadays almost all companies, at any level, and especially SMEs, use the Internet in their daily work. Human society has experienced different stages of development (economic, social, etc.), each of which leads to higher levels of organization and functioning (Skilton \& Hovsepian, 2018).

The history evolution of human society has been divided into 6 eras: the stone era, the iron era, the agriculture era, the industry era, the technology (information) era and the knowledge era. All these eras were known as revolutions, beginning with the interruption of migration, and ending with the present era, or that which secured the transfer of human skill and, more precisely, a part of the intelligence. Once the e-commerce has become the

DOI: 10.2478/picbe-2019-0042, pp. 479-491, ISSN 2558-9652| Proceedings of the $13^{\text {th }}$ International Conference on Business 
latest "rage" of modern technologies in the late ' 90 and the Internet, World Wide Web and other information technologies have rapidly transformed economic and social environment, many analysts, journalists and scientists have begun to reflect more and more on current transformations and discoveries and to place them in a broad, historical context. The outcome of these happenings was the conception of the present age as an Information Revolution, similar in its historical importance and its impact to previous economic revolutions, especially the industrial revolution (Schwab, 2016; 2018).

\section{The Fourth Industrial Revolution}

The Information Revolution, also called the Third Industrial Revolution or the Technical and Scientific Revolution, as well as many other historical periods, was not as sudden as cataclysm, as its name could suggest. Rather, everything associated with the Information Revolution is rooted in the industrial age. The bases of the informational age have been laid down since the 1940s, during the Second World War. Just like the steam engine during the Industrial Revolution, Information and Communication Technology (ICT) has completely changed the way the company organizes its economic activity. This period was marked by significant government investment in new technologies which included electronic devices and computers that were widely in the business world. Until the end of the sec. XX, the most important economic sectors, particularly in the United States of America, were those involving computers, electronic equipment, telecommunications, high technology and the related services sector. Throughout these processes, these technologies have ushered in the information economy, centered on knowledge-based industries (Homocianu, 2005).

Similar to previous revolutions, the Information Revolution is based on a series of technological breakthroughs. In this case, developments in the field of electronic devices and information technologies (computer, internet, etc. ) ensured economic change. The Informational Revolution took a critical turning in year 1959, when two scientists, Jack Kilby from Texas Instrument and Robert Noyce from Fairchild Semiconductor - came almost simultaneously to the "recipe" of the silicon chip, the device that enrolled electronic information in a space microscope, allowing the production and mass sale of computers (PCs). With extensive memory storage capability, faster computation and more in-depth control introduced into a microscopic chip, computers were ready to take a central role in economic life (Banabic, 2016; Gabrys, 2016).

Following this discovery, computers have become a focus of infrastructure in IT, from telephone networks in an office to controlling systems of transport for industrial plants and production, setting the stage for more discoveries data by their communication power, which has been unleashed by the Internet. The Internet and mobile phones have made everyone more aware than ever of the Information Revolution and its effects on the economy and society. It is supposed that the Information Revolution is also a new era of economic globalization, while geography is no longer a barrier to economic activity. We cannot say that the world economy has not been subjected to globalization before, especially at the end of the nineteenth century and early twentieth century's, but the process has been subject to the continuous reflux of the political and social changes. While cars of the 18th or 19th century replaced the worker in production, qualified/unqualified, the new "thinking machines" were increasingly capable of performing conceptual, leadership, and administrative functions or coordinating production flows, from raw 
material extraction to commercialization and distribution of goods and final services. Neither the Industrial Revolution has been inferior - this, in turn, has caused a high rate of unemployment and poverty, as well as a social and economic restructuring of society (Hadad, 2018).

In fact, the emergence and mass-generalization of the Internet, led to the Fourth Industrial Revolution (Industry 4.0). This is characterized by the use of cyber-physical systems in production processes and their connectivity (Schwab, 2016). The advanced technologies specific to the Fourth Industrial Revolution are: the Internet of Things (IoT), data processing, and, more recently, cloud manufacturing, Additive Manufacturing, Augmented Reality, Big Data, autonomous robots, process simulation, vertically and horizontally integrating systems (Schwab, K., 2018; Skilton \& Hovsepian, 2018).

The concepts of the Fourth Industrial Revolution are already included in the strategic development programs of all developed countries in Europe, America and Asia. Romania must be active in this qualitative leap of the world's industry, with some strengths to capitalize on, such as: the existence of a highly skilled workforce in the IT field; the existence of a highly-performing IT sector with competencies in areas essential to Industry 4.0: artificial intelligence, data security, Big Data, communication networks; the existence of research clusters in specific technologies for Industry 4.0 (Additive Manufacturing) or in the field of advanced modeling (stochastic modeling); involving university colleges in European projects in Industry 4.0; the existence of a high-performance internet infrastructure; the existence of an excellent collaboration with the German industry, the promoter of the Industry 4.0 concept (Banabic, 2016; Bratianu \& Bejinaru, 2017).

Especially in the last 20 years, the number of publications in this area has increased significantly. Relevant in this respect are: Pitt's Thinking about technology, which appeared in 2000 (Pitt, 2000) and Philosophy of Technology and Engineering Sciences, a voluminous treaty edited by Meijers and published in 2009, representing the volume of 9th edition of the famous Handbook of Philosophy of Science (Meijers, 2009). Later on Prensky (2009), he introduced a new "Digital Wisdom" concept that represents a person's ability to use new technologies to improve their cognitive performance, not only to understand them. Just as electricity has changed our lives 100 years ago, so will happen in a few years with Artificial Intelligence. Much of the decisions in everyday and professional life will be taken by systems embodying Artificial Intelligence. Is it okay, is it bad? The future will give us the answer to this question. According to figure no. 1 we have to answer the following questions: What will be the next step? When and what will be the next revolution?

From our point of view, the next industrial revolution will come about when the machines (tools) will reproduce themselves: they will think, design and realize by themselves the means (or tools) they need to perform the given tasks by the human subject. How far is this moment? Hard to say. Forecasts in this sense are already being made: there are already computer programs that "write" programs in their turn. Taking into account that the speed of implementation of a new invention in daily life is increasing, the moment of the next revolution can be estimated at some decades (Banabic, 2016). 


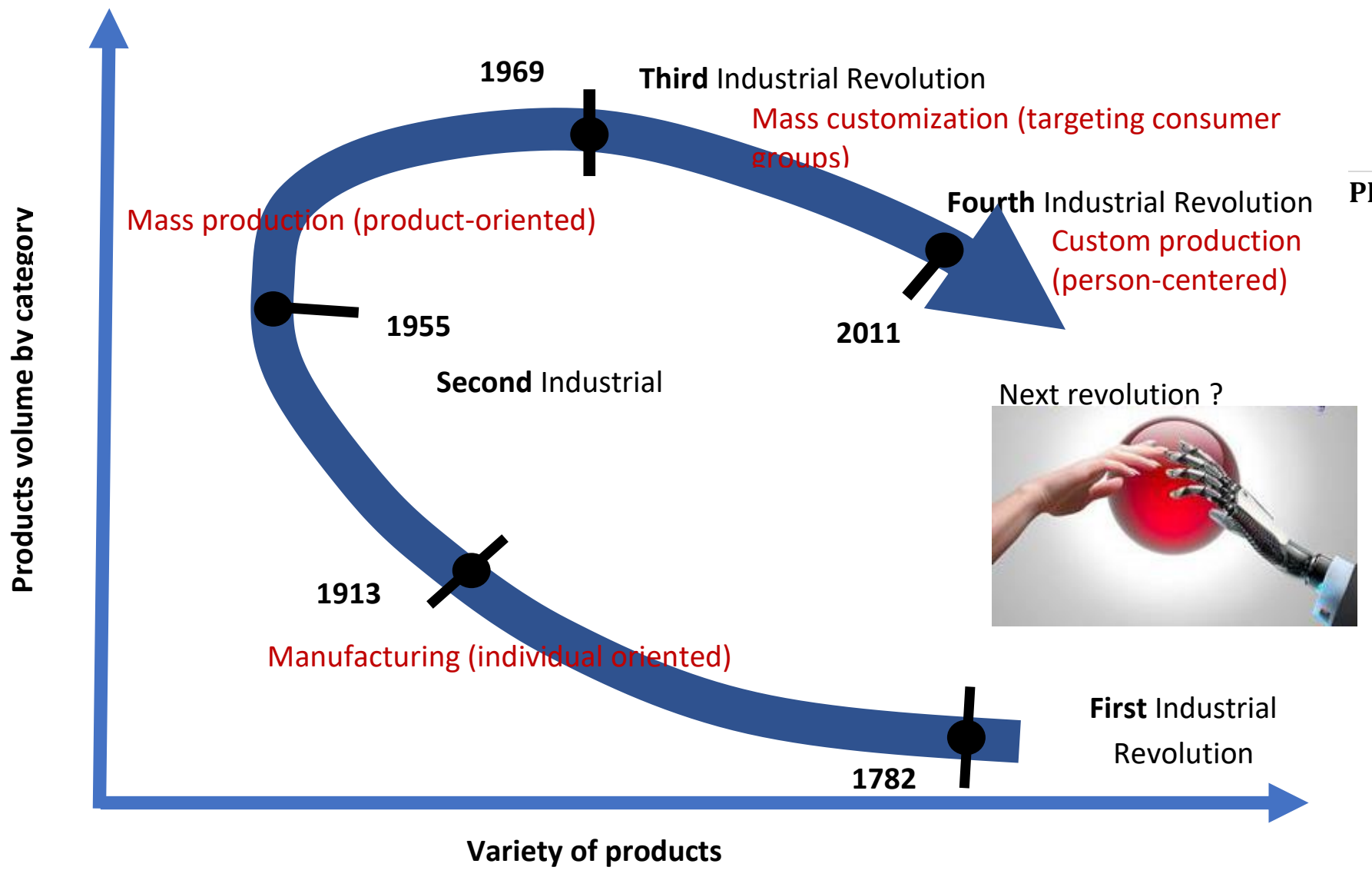

Figure 1. Cyclical evolution of technologies from the first to the fourth industrial revolution

Source: adapted after (Banabic, 2016)

\section{Interconnection between the business environment, industry 4.0. and workers}

Information and communication technologies have not only a social, but also a significant economic, cultural and political role. Currently the most profitable business is done through the Internet, the most successful business promotions are through social networking sites, blogs or sites, the best paid jobs are also online or and governments are increasingly turning to information products and services to make local or national public administrations more efficient (Cantaragiu et al., 2017; Zulean \& Prelipcean, 2013).

As the first three industrial revolutions have demonstrated that technology has a major impact on the labor market and the business environment, we expect the current phenomenon of accelerated digitization of the economy, known as the Fourth Industrial Revolution, to have positive effects on competitiveness, productivity, but also a notable impact on the labor market, on the creation or disappearance of jobs and the emergence of completely new occupations (Bratianu et al., 2011; Prelipcean \& Bejinaru, 2018).

Creating new business models based on increasing connectivity, reducing communication barriers and canceling distances, amplifying development factors, altering how value added is being created, leading to increased productivity. Therefore, when we talk about creating new business models, economic development of the country through

DOI: $10.2478 /$ picbe-2019-0042, pp. 479-491, ISSN 2558-9652| Proceedings of the $13^{\text {th }}$ International Conference on Business 
business, we also discuss the degree of competitiveness of a state through the prism of the ones mentioned above. Estimates of all or prospective studies in the past 10 years converge to the conclusion that the Fourth Industrial Revolution has certainly brought about major mutations in how to create added value, undeniably contributing to increased competitiveness. Intensification of the virtual nature of business relationships and increase connectivity networks to influence the whole lifecycle of the product to be integrated into the value chain. The user feedback can, for example, be translated directly into development software and therefore integrated into the product, thus leading to new business models (Hapenciuc et al., 2016).

The main technologies that will produce mutations in the structure of jobs will be robots and artificial intelligence. The main jobs in which new technologies will be found are those in which demanding or repetitive physical work is carried out, namely data collection /data processing. The first category includes trades in the field of machine building, metallurgy, mining, accommodation and food services, agriculture, handling and distribution of products, transport, care and rehabilitation of patients, etc. The second category includes the secretarial and archiving jobs, accounting, banking and insurance, translation, editing, etc. (Banabic, 2016; Unguru, 2016).

In such a context, a major role is played by higher education institutions that are shaping the future workers. In fact, the paradox is that universities are preparing students for jobs that presently don't exist yet. The world class universities have a strategic leadership for driving their educational outputs towards the best convergence with the environment. At this point, universities worldwide acknowledge that they must provide the essential skills or soft skills (Bratianu \& Vatamanescu, 2017) for increasing the chances of employability of the actual students and future knowledge workers in a turbulent business environment (Bejinaru \& Prelipcean, 2017). In this sense, we agree that "education and training suppliers should have the vision of their future as a dual model with the business sector in order to stay in touch with the market, to better meet the employers' needs" (Bratianu \& Bejinaru, 2016).

\section{Digitization as a driver of competitiveness growth}

In order to better quantify the information society as part of the knowledge-based society, specialists in the field used the calculation of indicators, thus trying to analyze their values to determine the situation of each state in the world from the point of view of ICT. In order to analyze comparatively the ICT situation and their impact on the business sector, two important indicators for this field were analyzed - the State ICT Development Index (IDI) and the DESI Index.

ITU ICT Development Index(IDI) is a unique indicator showing the level of ICT development in countries around the world as shown in Figure no. 1. IDI combines eleven indicators on ICT access, use and skills, capturing the key aspects of ICT development to an extent that allows comparisons between countries over time. If we were to compare IDIs worldwide, covering 176 economies, in recent years it would be noticed that index values continued to grow, with countries progressing in access and use of ICT. However, it also demonstrates that there are still large disparities in ICT development among the world's states. But it must also be understood that states need to become more 
and more connected and more ICT-enabled if they want to become inclusive information societies, thus contributing to sustainable development and other international goals.

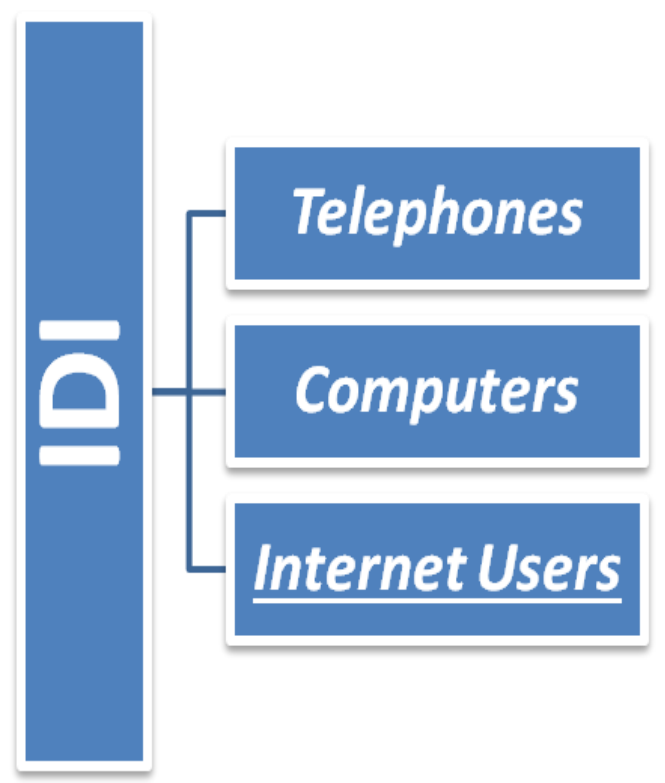

PICBE | 484

Figure 2: Structure of their ICT development index (IDI)

Source: www.worldbank.org/kam and www.itu.int

The Digital Economy and Society Index, DESI, is a composite index that integrates a set of relevant indicators, structured around five dimensions/components:

1. Connectivity, which reflects the level of development of the minimum physical infrastructure necessary for the digital economy, namely the existence of high-speed connections (broadband internet);

2. Human capital is the second component of DESI and illustrates the skills needed to take advantage of the opportunities offered by a digital society, from a basic user (online interaction and consumption of digital goods and services) to advanced skills (using digital technologies to increase productivity). Digital competences come to complement the infrastructure picture needed for the digital economy;

3. The use of the Internet, the third dimension of the composite index, measures the various online activities of the public who connect to the Internet: online content consumption (music, video, games), online communication, online banking and shopping;

4. The integration of digital technologies, the fourth component of DESI, measures enterprise digitization and the exploitation of the online sales channel. By adopting digital technology, companies can increase their efficiency, reduce costs and streamline their relationships with customers, collaborators, and business partners. Internet sales expand access to markets, increasing the potential for business growth;

5. Digital public services - the fifth dimension of the composite index - which measures the digitization of public services, with an emphasis on e-government. Examples of advanced countries demonstrate that modern public services contribute to increasing efficiency both for public administration, citizens and businesses. 
The integration of digital technologies, the fourth component of DESI, measures enterprise digitization and the exploitation of the online sales channel.

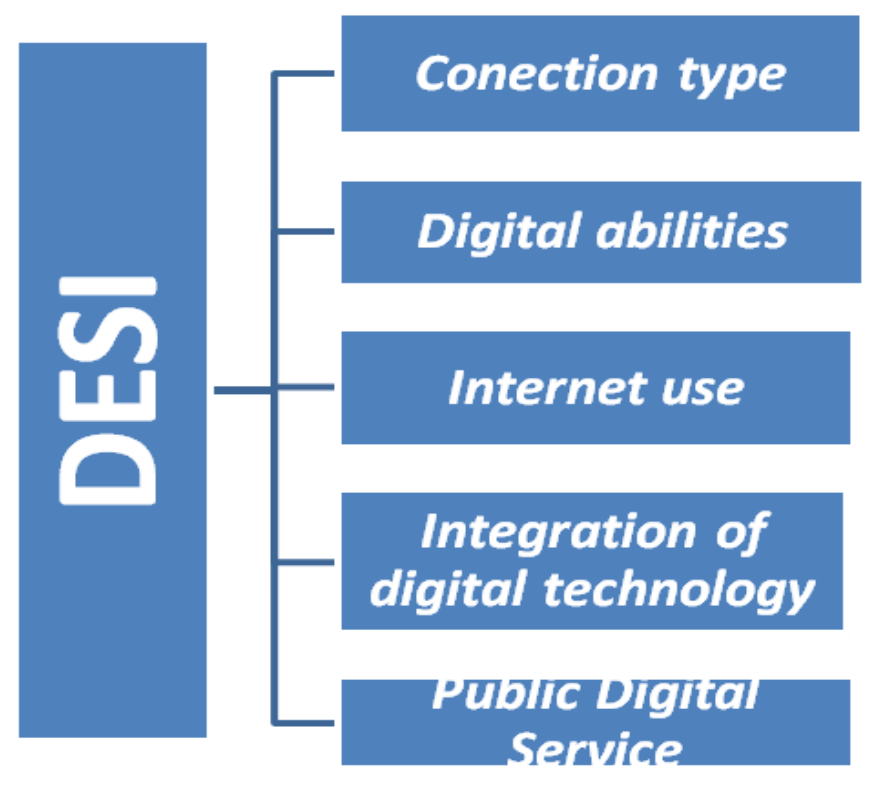

PICBE | 485

Figure 3. DESI structure

Source: Processed according to https://ec.europa.eu/digital-single-market/en/desi

Most DESI indicators come from Eurostat surveys, the European Union's statistical office. Certain broadband indicators are collected by the Commission services in the Member States through the Communications Committee. Other indicators are derived from studies prepared for the Commission (e.g. some eGovernment and broadband indicators). In conclusion, IDI is a more general indicator, a macroeconomic indicator, while DESI shows the more specific values of the country regarding the impact of ICT on the economic development of a state. Therefore, we consider both indices relevant in this study.

IDI allows us to see the general image of states and the attractiveness of current investments and the interest that a country can bring to foreign investors while DESI shows the impact of new technologies on the domestic situation and the mechanisms that give life to the daily activities of companies and people in particular. With DESI we can track how much the government invests in digitizing the economic activities of market players.

\section{Comparative study Romania - EU regarding IDI and DESI indices}

Table 1: Top EU Member States based on global ICT Development Index 2010 - 2017

\begin{tabular}{|c|c|c|c|c|c|c|c|}
\hline \multirow{2}{*}{ Nr.Crt. } & \multirow{2}{*}{$\begin{array}{l}\text { Country } \\
\text { Economy }\end{array}$} & \multirow[t]{2}{*}{ / } & $\begin{array}{l}\text { Rank } \\
\text { IDI }\end{array}$ & \multicolumn{4}{|c|}{ The ICT Index (IDI) } \\
\hline & & & Year & 2017 & 2016 & 2015 & 2010 \\
\hline 1. & Denmark & & 4 & 8.71 & 8.68 & 8.88 & 8.18 \\
\hline 2. & UK & & 5 & 8.65 & 8.53 & 8.75 & 7.62 \\
\hline 3. & Netherlands & & 7 & 8.49 & 8.40 & 8.53 & 7.82 \\
\hline
\end{tabular}

DOI: 10.2478/picbe-2019-0042, pp. 479-491, ISSN 2558-9652| Proceedings of the $13^{\text {th }}$ International Conference on Business Excellence 2019 


\begin{tabular}{|l|l|l|l|l|l|l|}
\hline $\mathbf{4 .}$ & Luxembourg & 9 & 8.47 & 8.40 & 8.59 & 7.82 \\
\hline $\mathbf{5 .}$ & Sweden & 11 & 8.41 & 8.41 & 8.67 & 8.43 \\
\hline $\mathbf{6 .}$ & Germany & 12 & 8.39 & 8.20 & 8.22 & 7.28 \\
\hline $\mathbf{7 .}$ & France & 15 & 8.24 & 8.05 & 8.12 & 7.22 \\
\hline $\mathbf{8 .}$ & Estonia & 17 & 8.14 & 8.16 & 8.05 & 6.70 \\
\hline $\mathbf{9 .}$ & Ireland & 20 & 8.02 & 7.90 & 7.82 & 7.04 \\
\hline $\mathbf{1 0 .}$ & Austria & 21 & 8.02 & 7.70 & 7.67 & 6.90 \\
\hline $\mathbf{1 1 .}$ & Finland & 22 & 7.88 & 7.83 & 8.36 & 7.96 \\
\hline $\mathbf{1 2 .}$ & Malta & 24 & 7.86 & 7.65 & 7.52 & 6.67 \\
\hline $\mathbf{1 3 .}$ & Belgium & 25 & 7.81 & 7.70 & 7.88 & 6.76 \\
\hline $\mathbf{1 4 .}$ & Spain & 27 & 7.79 & 7.61 & 7.66 & 6.53 \\
\hline $\mathbf{1 5 .}$ & Cyprus & 28 & 7.77 & 7.30 & 6.37 & 5.75 \\
\hline $\mathbf{1 6 .}$ & Slovenia & 33 & 7.38 & 7.20 & 7.23 & 6.69 \\
\hline $\mathbf{1 7 .}$ & Latvia & 35 & 7.26 & 7.05 & 7.16 & 6.22 \\
\hline $\mathbf{1 8 .}$ & Croatia & 36 & 7.24 & 6.96 & 7.00 & $5.82 *$ \\
\hline $\mathbf{1 9 .}$ & Greece & 38 & 7.23 & 7.08 & 7.09 & 6.20 \\
\hline $\mathbf{2 0 .}$ & Lithuania & 41 & 7.19 & 6.97 & 7.08 & 6.02 \\
\hline $\mathbf{2 1 .}$ & Czech Republic & 43 & 7.16 & 7.06 & 7.21 & 6.30 \\
\hline $\mathbf{2 2 .}$ & Portugal & 44 & 7.13 & 6.88 & 6.93 & 6.15 \\
\hline $\mathbf{2 . 3 .}$ & Slovakia & 46 & 7.06 & 6.84 & 6.82 & 5.96 \\
\hline $\mathbf{2 4 .}$ & Italy & 47 & 7.04 & 6.84 & 7.12 & 6.38 \\
\hline $\mathbf{2 5 .}$ & Hungary & 48 & 6.93 & 6.74 & 6.82 & 5.92 \\
\hline $\mathbf{2 6 .}$ & Poland & 49 & 6.89 & 6.73 & 6.91 & 6.38 \\
\hline $\mathbf{2 7 .}$ & Bulgaria & 50 & 6.86 & 6.66 & 6.52 & 5.45 \\
\hline $\mathbf{2 8 .}$ & Romania & 58 & 6.48 & 6.23 & 6.11 & 4.99 \\
\hline $\mathbf{2 9 .}$ & EUaverage & - & $\mathbf{7 . 4 2}$ & $\mathbf{7 . 5 0}$ & $\mathbf{7 . 5 3}$ & $\mathbf{6 . 6 8}$ \\
\hline & & & & & \\
\hline
\end{tabular}

Source: Processed after www.worldbank.org/kam and http://www.itu.int

* Even if Croatia joined the European Union only in 2013, it was taken into account at the EU average for the whole analyzed period (2010-2017).

Analyzing the data from the previous table 1, it is noticed that the value of IDI at EU-28 level in 2017 is 7.42, while Romania's IDI is almost one point lower (6.48), ranking last in the European rankings and 58th in the world. The most developed EU country according to IDI in the past 3 years is Denmark, with values of more than 8.5, in 2017 being ranked 4th in the world. This is followed by the United Kingdom, the Netherlands and Luxembourg, all of them ranking in the Top 10 World in 2017.

It is also noticed that the EU average of IDI has been steadily declining over the last 3 years, but has seen a significant increase over five years (2010-2014) during a world economic crisis. This decline was largely due to the significant development of ICT in Asia and Eastern Europe, as more and more Western IT companies outsource their businesses or move their branches to these markets, where spending is much lower compared to the European market.

The DESI index at the EU-28 level (presented in table 2) has also changed in recent years. However, Member States did not record changes in the positions occupied in the TOP EU-28 and some insignificant changes in the ranking in the world ranking. Romania continues to remain in the queue, although it has experienced significant paradigm shifts and ICT changes and reforms have taken place. 
Table 2 : DESI UE-28, 2018

\begin{tabular}{|c|c|c|c|}
\hline \multirow{2}{*}{ Nr.Crt. } & \multirow{2}{*}{$\begin{array}{l}\text { Country / } \\
\text { Economy }\end{array}$} & $\begin{array}{l}\text { Rank } \\
\text { ALTHOUGH }\end{array}$ & \multirow{2}{*}{$\begin{array}{l}\begin{array}{l}\text { DESI } \\
\text { index }\end{array} \\
2018 \\
\end{array}$} \\
\hline & & Year & \\
\hline 1. & Denmark & 1 & 95.43 \\
\hline 2. & Netherlands & 2 & 94.59 \\
\hline 3. & Sweden & 3 & 90.58 \\
\hline 4. & Finland & 4 & 88,80 \\
\hline 5. & Luxembourg & 5 & 88.46 \\
\hline 6. & Belgium & 6 & 84.48 \\
\hline 7. & UK & 7 & 83.63 \\
\hline 8. & Estonia & 8 & 82.65 \\
\hline 9. & Spain & 9 & 82.64 \\
\hline 10. & Austria & 10 & 81.71 \\
\hline 11. & Ireland & 11 & 81.63 \\
\hline 12. & Malta & 12 & 81.42 \\
\hline 13. & Slovenia & 13 & 80.02 \\
\hline 14. & Lithuania & 14 & 79.98 \\
\hline 15. & Germany & 15 & 79.73 \\
\hline 16. & EU average & - & 79.04 \\
\hline 17. & Portugal & 16 & 77.16 \\
\hline 18. & Rep. Czech & 17 & 75.48 \\
\hline 19. & Latvia & 18 & 71.87 \\
\hline 20. & Cyprus & 19 & 70.86 \\
\hline 21. & Slovakia & 20 & 69.92 \\
\hline 22. & Poland & 21 & 69.83 \\
\hline 2.3. & Croatia & 22 & 69.43 \\
\hline 24. & Hungary & 2.3 & 69.17 \\
\hline 25. & France & 24 & 68.59 \\
\hline 26. & Italy & 25 & 67.84 \\
\hline 27. & Bulgaria & 26 & 62.26 \\
\hline 28. & Greece & 27 & 57.36 \\
\hline 29. & Romania & 28 & 56.56 \\
\hline
\end{tabular}

PICBE | 487

Source: https://ec.europa.eu/digital-single-market/en/desi and Country Report for Romania on DESI

In 2017, the DESI values were small compared to 2018 and higher compared to previous years. This is due to certain categories of sub-indicators of indicators that have grown, and less significant were changes in indicators with a smaller share of the calculation. Thus, the EU-28 average in 2017 was nearly 60, much lower than last year (2018), and Romania was also ranked last in the Rankings. This shows once again the rhythm of the development of the ICT sector in the world and in society. 


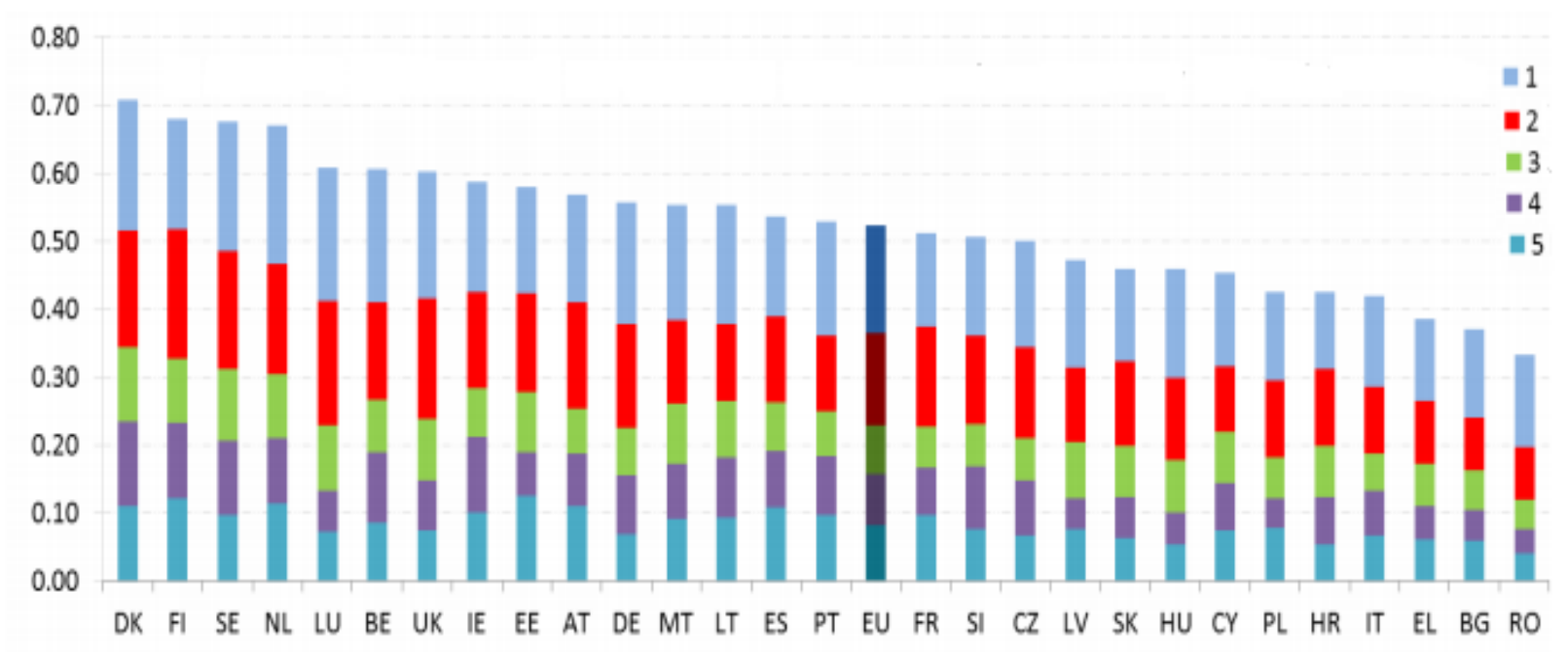

PICBE | 488

Figure 4. DESI UE-28, 2017

Source: Country Report for Romania on the Economy and Digital Society (DESI) for 2018

Where:

1. - Connectivity

2. - Human Capital

3. - Using the Internet

4. - Integration of digital technologies

5. - Digital public services

DG CONECT (2016) and Eurostat rankings in 2017 and 2018 position Romania the last in the EU at DESI level although the situation on components is not homogeneous (Figure 4 and Table 2). Its score has increased, thanks to an improvement in performance in four of the five DESI sizes. However, progress in recent years has been slow and Romania has failed to catch up.

The level of digitization of the economy, as well as the digital competences of the population, are low and make it difficult to make progress with most DESI dimensions. On the other hand, $44 \%$ of Romanian homes are subscribed to high-speed broadband services (ranked second in speed in the EU). The ICT sector is responsible for 6-7\% of Romania's GDP, and the digital sector is growing, with two major hubs in Bucharest and Cluj and significant ICT investments in other cities. According to the data reported by Romania's Country Report regarding Digital Economy and Society Index 2018, it is part of the cluster countries with low performance (DESI Country Report, 2018).

Romania's progress in the field of information society and its future opportunities are far from being fruitful. There are delays, in particular, in terms of access to the Internet, information society services and integration of IT (Information Technology) applications into the economy. Although Romania has made significant progress in recent years, our country continues to be the last in the EU ranking of IDI or DESI indices. Even at 12 years from EU accession, Romania is lagging behind the EU-28 average. This has a negative effect on state competitiveness, because the use of ICT - computers, internet access and knowledge - are major factors in the development of the economy (Vizitiu et al., 2017). Even if the evolution of the IT market in Romania shows that IT equipment 
purchases have increased significantly and the Internet connection rate, and that many corporations in the field are opening more and more branches here, Romania still maintains the last position in the DESI of the EU-28. An analysis of the impact on the Romanian economic environment of business based on new technologies is currently being carried out by the Romanian Competition Council (started yet in 2018), the study will provide the specialists with the information needed to develop new rules. Thus, according to the president of the Romanian Competition Council, the analysis focuses on new types of business such as Uber and Airbnb, in order to facilitate their access on the Romanian market but under the restraints of keeping the balance compared to the old companies. According to the representatives of the Romanian Competition Council, various legislative reforms are also considered to facilitate the access of new companies, which will come up with a significant know-how and high-tech resource for the Romanian market.

\section{Conclusion}

Many studies in recent years lead to the conclusion that the Fourth Industrial Revolution (Information Revolution) has brought decisive changes in the global economic system and will lead to further significant mutations. Due to the implications of ICT in economic and social life, market competitiveness and productivity have increased. It is also possible to discuss another kind of added value now. Therefore, due to increased productivity, due to business digitization, opportunities have been created for companies and employees, the global market and the world economic system have changed irremediably (Bejinaru, 2017).

From the point of view of IDI and DESI at EU level, we could conclude that Europe's economy is declining slightly, and even if it maintains positions in terms of modern information technology and innovation, it stagnates, being overtook by economies in the Orient.

Following the analysis of the situation in Romania regarding the ICT level in the country, it was noticed that regardless of whether IDI or DESI values have increased in recent years, IT spending in GDP is still low compared to the EU-28 average. The development of information society-specific infrastructure is still insufficient and requires reforms. Another barrier to business development in our country is the high level tariffs for access to ICT infrastructure and new government-approved laws, which slows down the economic development of the country through ICT and business interfaces.

\section{References}

Archives of INSSE, "Information Society ", http://www.insse.ro

Banabic, D. (2016). Industry 4.0 started. Is it ready Romania for the challenges of this new revolution?, Revista de Politica Ştiintei si Scientometrie - Serie Noua, 5(3), p. 194-201.

Bejinaru, R. \& Prelipcean, G. (2017). Successful strategies to be learnt from world-class universities, The 11th International Conference on Business Excellence Strategy, Complexity and Energy in changing times, 30-31 March 2017, Bucharest, University of Economic Studies, pp. 469-492, De Gruyter Open, 11(1) July 2017.

Bejinaru, R. (2017). Knowledge Strategies Aiming to Improve the Intellectual Capital of Universities, Management \& Marketing. Challenges for the Knowledge Society, Vol. 12, No. 3, pp. 500-523. 
Bratianu, C. \& Bejinaru, R. (2016). Evaluation of knowledge processes within learning organization. In: O. Nicolescu, L. Lloyd-Reason (Eds.). Challenges, performances and tendencies in organization management (pp.125-136). Singapore: World Scientific.

Bratianu, C. \& Bejinaru, R. (2017). Knowledge strategies for increasing IC of universities. In Lopez, I.T. \& Serrasqueiro, R. (Eds.). Proceedings of the $9^{\text {th }}$ European Conference on Intellectual Capital, Instituto Universitario de Lisboa (ISCTE), (pp. 34-42), Portugal, 6-7 April 2017. Reading: Academic Conferences and Publishing International.

Bratianu, C., Agapie, A. \& Orzea, I. (2011). Knowledge dynamics modeling using Analytic Hierarchy Process (AHP). In Turner, G. \& Minnone, C. (Eds.). Proceedings of the $3^{\text {rd }}$ European Conference on Intellectual Capital (pp. 94-102), 18-19 April 2011, University of Nicosia, Cyprus. Reading: Academic Conferences and Publishing International.

Bratianu, C. \& Vatamanescu, E.M. (2017). Students' perception on developing conceptual generic skills for business: A knowledge-based approach. VINE Journal of Information and Knowledge Management Systems, Vol. 47, No. 4, pp. 490-505.

Cantaragiu, R., Paunescu, C. \& Hadad, S. (2017). The social impact of university entrepreneurship in Romania: Is the institutional discourse replicated or adapted? Management \& Marketing 9 (4), 403.

Country Report for Romania on the Digital Economy and Society (DESI) for 2018 , https://ec.europa.eu/digital-single-market/en/desi

Drucker, P. (2001).The Future Organization, Teora Publishing House, Bucharest.

Gabrys, J. (2016). Digital Rubbish. A Natural History of Electronics, University of Michigan Press.

Ghinea, V.M., Dima, A.M. \& Hadad, S. (2017). Excellence Model for Sustainable Convergence in the EU Higher Education, Amfiteatru Economic 19 (11), 1107-1122.

Hadad, S. (2018). The geographic distribution of Knowledge Economy (KE) within the European Union (EU), Management \& Marketing 13 (3), 1089-1107.

Hapenciuc, C.V., Bejinaru, R., Roman, C. \& Neamtu, D.M. (2016). The Role Of HES Within The Evolution Of The Business Sector, EDULEARN-8th annual International Conference on Education and New Learning Technologies Barcelona (Spain). 4th - 6th of July, 2016.

Homocianu, D. (2005). Based on knowledge - more than metaphor in present and future realities , Scientific Annals of "Alexandru Ioan Cuza" University of Iasi, Tom L / LI, Iaşi $2004 / 2005$

Meijers, A. (Ed.) (2009). Philosophy of Technology and Engineering Sciences, Elsevier, Amsterdam.

Michaels, J. W. (1999). How new is the new economy? Forbes No. 11.

Pitt, J. C. (2000). Thinking about technology: foundations of the philosophy of technology, Seven Bridges Press, New York.

Prensky, M., H. (2009). Sapiens Digital: From Digital Immigrants and Digital Natives to Digital Wisdom.

Prelipcean, G. \& Bejinaru, R. (2018). University Agenda For Developing Students' Skills In The Knowledge Economy, Strategica -International Conference - Sixth Edition, "Challenging the Status Quo in Management and Economics", Bucharest: 11th -12th October, pp. 600-610. 
Regional Development Plan 2007-2013 West Region, Cap. IX: Information Society , https://adrvest.ro/planul-de-voltare-regionala-2007-2013-4/

Rifkin, J. (2004).The End of Work: The Decline of the Global Labor Force and the Dawn of the Post-Market Era, Jeremy P. Tarcher / Penguin, New York.

Schwab, K. (2018). Shaping the Fourth Industrial Revolution, WEF, Geneve.

Schwab, K., (2016). The Fourth Industrial Revolution, WEF, Geneve.

PICBE | 491

Skilton, M. \& Hovsepian, F. (2018). The 4thIndustrial Revolution, Palgrave, London.

The National Digital Agenda for Romania, www.comunicatii.gov.ro

Unguru, M. (2016). The impact of the digitization of the economy on competitiveness and the labor market, Annals of the Conference Impact of socio-economic and technological transformations at national and European level, electronic source

Vizitiu, C., Agapie, A., Paiusan, R., Hadad, S. \& Nastase, M. (2018). Adapting corporate entrepreneurship assessment instrument for Romania, South African Journal of Business Management 49 (1), 7.

Zulean, M. \& Prelipcean, G. (2013). Emergency preparedness in Romania: Dynamics, shortcomings and policy proposals, Technological Forecasting and Social Change 80 (9), 1714-1724. 